\title{
MATERIALNE ŚLADY MINIONEJ ZALEŻNOŚCI I ICH WSPÓŁCZESNE ODCZYTANIE W PRZESTRZENI MIEJSKIEJ SZCZECINA
}

\author{
MAŁGORZATA PRACZYK ${ }^{1}$ \\ (Uniwersytet im. Adama Mickiewicza w Poznaniu)
}

Słowa kluczowe: postkolonializm, kolonializm, przestrzeń miejska, Szczecin, architektura

Key words: postcolonial studies, colonialism, urban space, Szczecin, architecture

\begin{abstract}
Abstrakt: Małgorzata Praczyk, MATERIALNE ŚLADY MINIONEJ ZALEŻNOŚCI I ICH WSPÓŁCZESNE ODCZYTANIE W PRZESTRZENI MIEJSKIEJ SZCZECINA. „PORÓWNANIA” 17, 2015. T. XVII. S. 123-138. ISSN 1733-165X. Artykuł omawia kwestie relacji polsko-niemieckich oraz polsko-radzieckich w perspektywie kolonialnej i postkolonialnej, w kontekście przestrzeni miejskiej Szczecina. Zastosowanie narzędzi badawczych dostarczanych przez krytykę postkolonialną rzuca nowe światło na krajobraz kulturowy miasta i pozwala wydobyć jego specyficzną, pograniczną tożsamość. Decyzje dotyczące tego, co i w jaki sposób odbudowywano w mieście, które po zakończeniu II wojny światowej jako polskie, znalazło się w radzieckiej strefie wpływów, były bardzo wieloznaczne. Odbudowa Szczecina sytuująca się między niemieckim dziedzictwem a balastem radzieckiej zależności powodowała szereg trudności w oswojeniu miasta przez zasiedlających je Polaków oraz wpłynęła na wytworzenie odrębnych mechanizmów umożliwiających zakorzenienie $\mathrm{w}$ nim oraz utożsamienie się z jego miejską tkanką.
\end{abstract}

Abstract: Małgorzata Praczyk, MATERIAL TRACES OF PAST DEPENDENCY AND ITS CONTEMPORARY READING IN THE URBAN SPACE OF SZCZECIN. "PORÓWNANIA" 17, 2015. Vol. XVII. P. 123-138. ISSN 1733-165X. The article deals with the question of Polish-German and Polish-Soviet relations from the colonial and postcolonial perspective in the context of the urban space of Szczecin. The application of theoretical categories provided by the postcolonial studies helps to perceive the cultural landscape of the city in a different way and enables to bring out its specificity and border condition. Decisions concerning what was to be rebuilt and the way it was to be rebuilt in the city after World War II, which became Polish but situated in the area of the

\footnotetext{
${ }^{1}$ Correspondence Address: malgorzatapraczyk@gmail.com
} 
soviet influence, were multidimensional. The reconstruction of the city had to be defined somewhere between the German heritage and the ballast of the soviet domination. In consequence this situation caused many difficulties both in the process of growing accustomed to the city and in enabling the identification with its material, architectural texture by its new, Polish inhabitants.

Przemyślenie powojennej historii Szczecina w kategoriach dostarczanych przez krytykę postkolonialną pozwala dostrzec szereg złożonych relacji zależnościowych, jakie występowały i występują w tym mieście przede wszystkim w kontekście relacji polsko-niemieckich oraz polsko-radzieckich. Szczecin, podobnie jak inne polskie miasta, nigdy nie był miastem kolonialnym, a więc i postkolonialnym par excellence. W mieście kolonialnym kolonizatorzy i kolonizowani funkcjonują wspólnie w przestrzeni miasta wytwarzając skomplikowane relacje wzajemne oraz dzieląc na różne sposoby przestrzeń miasta między siebie (Kotkin 126-136), (Hannertz 141-192). Kolonizatorzy wszczepieni są wtedy w tkankę miasta zarówno w znaczeniu przenoszenia wpływów kulturowych, jak i swojej fizycznej obecności. W przypadku Szczecina nie mieliśmy do czynienia z taką sytuacją.

Mimo to narzędzia badawcze, których dostarczają studia postkolonialne, a na gruncie polskim studia postzależnościowe, dają się z powodzeniem zaaplikować do polskich realiów i pozwalają wydobyć zniuansowaną specyfikę Szczecina i rzucić nowe światło na jego kulturową, materialną tkankę (Kołodziejczyk 2011: 117-136; Kołodziejczyk 2013: 9-27). Kategorie różnicy, podrzędności i oswajania, które śmiało można wykorzystać analizując historię Szczecina, prowadzą do zredefiniowania w kategoriach postzależnościowych tożsamości lokalnej i pogranicznej omawianego miasta. Proponowana tu refleksja wpisuje się $\mathrm{w}$ społecznokulturowy obszar badań mieszczących się $\mathrm{w}$ polskim dyskursie postzależnościowym, którego ramy zarysował Ryszard Nycz w znaczeniu badania heterogenicznej tożsamości miasta czy relacji z miejscem (Nycz 8-9). Niniejszy tekst stanowi więc próbę przeanalizowania miasta, które nie jest miastem kolonialnym w dosłownym znaczeniu, narzędziami krytyki postkolonialnej, których status okazuje się na tyle uniwersalny, że daje się zaaplikować do tego typu badań.

Tożsamość kulturowa Szczecina, która ujawnia się w architekturze, nazewnictwie ulic i placów czy pomnikach, nacechowana jest kondycją kolonialną i postkolonialną. Fakt ten uwidacznia się $\mathrm{w}$ praktykach kulturowego kolonizowania przestrzeni miejskiej (co odbywało się w Szczecinie dwustopniowo: zarówno w stosunku do niemieckości miasta, jak i w stosunku do zdeterminowanej ideologicznie na zasadzie podrzędności polskości miasta w czasach komunizmu) oraz w praktykach dekolonizacyjnych, które ujawniają się w Szczecinie po 1989 roku. 


\section{Symboliczne kolonizowanie miasta - relacje polsko-niemieckie}

Pisząc o Szczecinie w perspektywie postzależnościowej, nie można pominąć wątku relacji polsko-niemieckich w czasach tuż po II wojnie światowej. Bez ich przywołania trudno jest zrozumieć relację zależnościową, w której znalazło się miasto $\mathrm{w}$ kontekście wpływów radzieckich, a także problemu otrząsania się z radzieckiej zależności po 1989 roku.

Szczecin to przede wszystkim miasto o długiej, niemieckiej tradycji, co było $\mathrm{i}$ jest do dziś dostrzegalne $\mathrm{w}$ jego miejskiej przestrzeni. Polacy, którzy zasiedlali miasto po zakończeniu II wojny światowej kolonizowali miasto w sensie symbolicznym, próbując zmienić tożsamość jego pejzażu kulturowego (Muskamp 160). Nie kolonizowali jednak niemieckich mieszkańców miasta. Zmiana granic terytorialnych Polski po II wojnie światowej wiązała się z wysiedlaniem Niemców z przyłączonych terytoriów, co skutkowało uniknięciem sytuacji kolonialnej w sensie praktycznym. Polscy osadnicy w Szczecinie, sami poddani podobnym represjom jako wysiedleńcy ze wschodnich terenów międzywojennej Polski, nie wytworzyli w mieście trwałych relacji kolonizator - kolonizowany, jakie są charakterystyczne dla klasycznych społeczeństw kolonialnych (Muskamp 71-157)². Mimo tego, nie można zignorować istotnej kwestii świadczącej o kondycji postkolonialnej Polaków w stosunku do Niemców wysiedlonych z omawianych terenów. Pamięć o przesiedleniach oraz sposób wkroczenia w niemiecką przestrzeń kulturową, nacechowany wzmacnianym ideologicznie poczuciem słusznego „odzyskiwania polskich ziem" i dokonującej się „sprawiedliwości dziejowej”, nosiły i noszą do dziś znamiona kolonialnej przemocy, która sytuuje Polaków także w roli ciemiężców (Snochowska-Gozales 23).

W latach tuż po zakończeniu wojny mechanizmom kolonialnym podlegali jednak nie tyle Niemcy, ile to, co po nich pozostało - materialne świadectwa ich obecności. W przypadku Szczecina Polacy znaleźli się zatem w pozycji kolonizatorów krajobrazu kulturowego, a nie w sensie praktyki politycznej czy społecznej. I choć zabiegi, których dokonywano w samej przestrzeni miejskiej niewątpliwie posiadały polityczny charakter, ich ostrze bezpośrednio wymierzone było w materialne, niemieckie dziedzictwo. Ból, który niemieccy mieszkańcy Szczecina mogli odczuwać z powodu podejmowanych przez Polaków działań, odnosił się do tego,

2 Relacje polsko-niemieckie o quasi-kolonialnym charakterze w Szczecinie można ewentualnie obserwować w kilku latach następujących zaraz po wojnie, aż do zakończenia procesu wysiedlania ludności niemieckiej ze Szczecina. Bardzo niewielka liczba Niemców, która zdecydowała się mimo wysiedleń pozostać w Szczecinie stanowiła już tylko nieznaczącą mniejszość. Na ten temat szeroko pisze w swej świetnej książce Jan Musekamp. J. Musekamp, Między Stettinem a Szczecinem. Metamorfozy miasta od 1945 do 2005. Poznań, 2013. S. 71-157. 
co niegdyś stanowiło przestrzeń ich codziennego życia i nacechowane było silnymi emocjami, jednak podlegali realiom politycznym powojennych Niemiec, nie Polski. Polityczna, praktyczna relacja zależnościowa pozwala raczej stworzyć analogię między Polakami a Niemcami znajdującymi się w radzieckiej strefie okupacyjnej, a potem żyjącymi w NRD, która oba narody sytuuje na tej samej płaszczyźnie wobec kolonizującego ich Związku Radzieckiego, jako sprawcy odpowiedzialnego za przesiedlenia obu narodów.

Symboliczne kolonizowanie Szczecina, które Jan Musekamp nazywa procesem kulturowego przyswajania miasta, polegało ponadto $\mathrm{w}$ mniejszym stopniu na czynieniu podrzędnymi świadectw niemieckiej kultury i niemieckiej obecności ile na „odniemczaniu” miasta (Musekamp 35). Było to istotne ze względu na różnice kulturowe i cywilizacyjne, na które napotykali przesiedlani Polacy. Wysiedleni na tereny znajdujące się na zachód od Szczecina Niemcy nie napotykali na takie trudności w przyswojeniu nowego krajobrazu kulturowego, ponieważ struktura organizacyjna, administracyjna, a także architektura i nazewnictwo były im dobrze znane (Brencz 191-196). Przybywający do Szczecina Polacy, zasiedlając niemieckie domy o obcym układzie musieli oswoić przestrzeń wyposażoną w obce im meble, obce sprzęty, a nawet obce gatunki roślin rosnące w przydomowych ogrodach czy w parkach (Brencz 194-195; 204-207).

Podobne odczucia $\mathrm{w}$ związku z odmiennymi warunkami życia ilustrują słowa Polki przybyłej do Szczecina z terenów ZSRR:

Byłam oszołomiona naszym mieszkaniem: dwa pokoje na parterze, trzy pokoje na piętrze i dwa pokoje na poddaszu, nieduży pokój z umywalką i ubikacją, na piętrze łazienka. Nigdy nie mieszkałam $w$ tak dużym mieszkaniu. Jeszcze przy domu ogródek z drzewami owocowymi (Turek 41-42).

Niemieckiego dziedzictwa kulturowo-cywilizacyjnego nie można było odrzucić w pełni. Polacy koncentrowali się zatem przede wszystkim na zmianie nazewnictwa ulic i placów, niszczeniu niemieckich napisów czy burzeniu niemieckich pomników. W przypadku Szczecina owo „odniemczanie” miasta przejawiało się także w nieodbudowywaniu niemieckiej architektury. Podobny wymiar miał także demontaż pozostałości niemieckiej infrastruktury, choć fakt ten posiadał znaczenie praktyczne i świadczył o nowej zależności, w jakiej znaleźli się Polacy po wojnie. Z pozyskanych materiałów odbudowywano zniszczoną przez Niemców Warszawę, ale też istotna część materiałów pochodzących z rozbiórek wędrowała do ZSRR (najbardziej jaskrawym przykładem jest tu przywoływana zazwyczaj rozbiórka infrastruktury stoczniowej) (Musekamp 89-92).

Działania polegające na czynieniu Szczecina polskim miastem podejmowano także w warstwie retorycznej i propagandowej, która włączała Szczecin w szereg mitów „ziem odzyskanych” (Musekamp 171-201). Mimo prób „repolonizacji” pejzażu Szczecina nie dało się jednak ominąć prostego faktu - to, co, mimo zniszczeń, 
pozostało z miasta - było niemieckie. Obok wymienionych wyżej działań niwelujących niemiecką strukturę miasta, owa „repolonizacja” polegała zatem na tym, co w Szczecinie budowano, oraz na tym, jak go odbudowywano. Ta płaszczyzna działań przenosi nas już jednak w sferę racji zależnościowych Polaków znajdujących się w realiach sowieckiej strefy wpływów.

\section{Polsko-radzieckie relacje zależnościowe}

W kontekście polskim i szczecińskim pozycja kolonizowanego może być odczytywana w odniesieniu do funkcjonowania w radzieckiej strefie wpływów. Podobnie jak w przypadku relacji polsko-niemieckich o kolonialnej tożsamości Szczecina nie można tu mówić w sensie dosłownym. Radziecka fizyczna obecność w mieście ograniczała się w zasadzie jedynie do stacjonowania radzieckich żołnierzy. Fakt ten posiadał istotne znaczenie $\mathrm{w}$ sensie militarnym oraz psychologicznym, jednak administrowanie miastem przypadło nie Rosjanom, ale Polakom. Kolonialna kondycja Szczecina ujawniała się, jak w przypadku całego kraju, w polityczno-gospodarczej podrzędności Polaków, a w przestrzeni miasta w przestrzeni symbolicznej. Tu jednak także sytuacja wydaje się bardziej skomplikowana. Zależność polsko-radziecka występowała bowiem bardziej na linii zależności polsko-polsko-radzieckiej. Polski komponent w drugim członie owej relacji stanowił bardzo istotny czynnik wpływający na sytuację społeczno-kulturową w powojennej Polsce. To działający z namaszczenia radzieckiego opresora Polacy w praktyce uzależniali Polskę od politycznego hegemona. Wieloznaczność tej relacji dobrze ilustruje postać profesora Piotra Zaremby, architekta, urbanisty i pierwszego polskiego prezydenta Szczecina po wojnie. Sprawujący ten (bądź co bądź, polityczny) urząd w latach 1945-1950, zapisał się pozytywnie w historii miasta, a motywacje, którymi kierował się przy okazji sprawowania funkcji prezydenta opierały się na patriotycznym przeświadczeniu o budowie nowego Szczecina (Zaremba 1986; Zaremba 1980: 11-22). Przy odbudowie zrujnowanej przez wojnę Polski istotną rolę odgrywał powszechnie panujący zapał patriotyczny, którego nie da się zignorować, mimo tego, iż często był wykorzystywany propagandowo i ideologicznie. Decyzje z zakresu urbanistyki, architektury, czy tzw. małej architektury (np. pomników), które znacząco definiują kulturową tożsamość miasta rozumianą jako symboliczną i materialną tkankę miejską, były decyzjami podejmowanymi przez Polaków. Niewątpliwie funkcjonowali oni w realiach radzieckiej strefy wpływów, co wiązało się z zaistnieniem szeregu ograniczających Polaków regulacji administracyjnych i prawnych, które podporządkowywały polską działalność obowiązującej ideologii komunistycznej (Basista 11-49; Kibort 12-13; 15-16). Decyzji przez nich podejmowanych nie da się jednak zaszufladkować na zasadzie prostego przełożenia radzieckich interesów na grunt polski, jak chce tego Agata Lisiak 
(Lisiak 139-143). Twierdzi ona na przykład, że: „prawie każdy blok mieszkalny, szkoła czy dom handlowy były naznaczone ideologią socjalistyczną. Co znajdowało odzwierciedlenie $\mathrm{w}$ ich wyglądzie, nazwisku patrona danego budynku czy też wybitnej karierze partyjnej ich architekta" (Lisiak 140). To znaczące uproszczenie. Powojenna rzeczywistość polskich miast jest bowiem daleko bardziej złożona, co z pełną mocą ujawnia się zresztą w różnorodnym stosunku Polaków do architektury powstającej w epoce powojennej.

Wróćmy w tym miejscu do Piotra Zaremby. Jego koncepcja odbudowy Szczecina, mocno akcentująca wydobycie polskiego charakteru miasta, opierała się o różnorakie inspiracje, między innymi płynące z redagowanej pod kierunkiem Le Corbusiera Karty Ateńskiej (Musekamp 252-253). Dokument ten, wypracowany na słynnym CIAM (Congrès Internationaux d'Architecture Modern) w 1933 roku w Atenach, miał trudny do przecenienia wpływ na architekturę i urbanistykę XX wieku na całym świecie. Działalność architektoniczna i urbanistyczna Polaków po wojnie $w$ Polsce, mimo ograniczeń narzuconych przez opresyjny system polityczny, znajdowała się także pod wpływem nowoczesnych wówczas idei wypływających poza granice "drugiego świata” (Basista 56-57). Projekt odbudowy górnej starówki w Szczecinie został wyróżniony w 1963 roku w Berlinie Wschodnim na konferencji RWPG, ale doceniono go także wcześniej, już w 1956 roku na konferencji ochrony zabytków UNESCO, która odbyła się w Paryżu (Musekamp 276-277).

Architektura i urbanistyka miast przebudowywanych i rozbudowywanych po II wojnie światowej w państwach bloku wschodniego w różnym stopniu uzależniona była od doktrynalnej matrycy. W Polsce czas największych ograniczeń przypadł na okres do roku 1956 (Szymski 15). Następujące potem stopniowe rozluźnianie ideologicznego gorsetu pozwalało na implementację modernizmu niejako w alternatywie do obowiązującej od 1949 roku doktryny socrealizmu (Szymski 21). Niejednokrotnie dziś krytykowane podejście ignorujące kontekst historycznej zabudowy Szczecina oraz zaniechania $\mathrm{w}$ zakresie prac remontowych, a także wyburzanie czy nieodbudowywanie niemieckiej zabudowy wynikało w dużej mierze z przenikających do Polski idei architektury modernistycznej. Jak zauważa Adam Szymski:

Było to wynikiem powszechnego wówczas wśród powojennego pokolenia architektów panującego przekonania, że podstawą tworzenia nowej struktury przestrzennej miasta winny być zasady wyłożone w słynnej „Karcie ateńskiej” z 1933 roku. Według zawartej w niej doktryny nie należało prowadzić remontów i odbudowy starych części miast, lecz dążyć do kompleksowej ich przebudowy, także poprzez sanację XIX wiecznej zabudowy kwartałowej (Szymski 51).

Ważny czynnik stanowił tu także brak emocjonalnej więzi z historyczną zabudową Szczecina oraz niechęć wobec tego, co niemieckie, co z kolei wpisywało się 
w linię politycznej propagandy dotyczącej zachodniego sąsiada Polski. Należy zaznaczyć, że niechęć ta nie została wykreowana zewnętrznie i nie była jedynie implementowanym wytworem propagandy. To obowiązująca linia propagandowa wykorzystywała zastaną już nieprzychylność Polaków wobec Niemców i wzmacniała ją, uznając za korzystne narzędzie dzielenia i potęgowania różnicy. W decyzjach dotyczących rozwoju urbanistycznego miasta decydująca była jednak popularność modernizmu. Ponadto powojenne oblicze modernizmu, z powodu ogromnej skali zniszczeń wojennych w europejskich miastach, odcisnęło szczególne piętno na budownictwie mieszkaniowym, gdzie funkcjonalny wymiar architektury modernistycznej mógł być doskonale realizowany. Architektura modernistyczna, rozumiana jako architektura nowoczesna i demokratyczna, ale też jako architektura prospołeczna, znajdowała akceptację także na wschodzie Europy, gdzie budowa osiedli mieszkaniowych również stanowiła priorytet. Działania polskich architektów pozostawały w ścisłym związku z nowoczesnymi trendami architektury światowej, na co także trafnie zwraca uwagę Szymski stwierdzając, że: „młodzi podówczas szczecińscy architekci z właściwym sobie zapałem »neofitów « jęli się prac projektowych z formy i ducha opartych »do żywego« na publikowanych w zawodowej prasie projektach i realizacjach budynków osiedli mieszkaniowych głównie w Niemczech, Francji i Anglii" (Szymski, 62-63).

Krytyka architektury modernistycznej zaczęła się pojawiać na polskim gruncie w końcu lat 70. XX wieku. Następująca zmiana pokoleniowa wśród architektów oraz pojawiające się już na świecie realizacje $w$ duchu architektury postmodernistycznej zaczęły stopniowo przenikać także do polskich pracowni architektonicznych. Nowe spojrzenie na architekturę przyjmowało się jednak niemal dekadę, a więc zerwanie $\mathrm{z}$ modernizmem na powszechną skalę zeszło się już $\mathrm{w}$ czasie z przełomem politycznym, dyktując architektom zupełnie odmienne warunki pracy (Szymski, 111-112). Warto mieć jednak na uwadze fakt, iż powstająca w Polsce architektura końca lat 70. i lat 80., podobnie jak i architektura wcześniejsza stanowiły rezultat przenikania się wielorakich wpływów z obu stron żelaznej kurtyny.

Podobnie wieloznacznie jawi się praktyka wytwarzania Hobsbawmowskiej nowej tradycji, która stanowi produkt polityki historycznej obowiązującej władzy, a przejawia się $\mathrm{w}$ przestrzeni miasta m.in. poprzez wznoszenie pomników czy zmianę nazw ulic (Hobsbawm 9-23), (Chrudzimska-Uhera 277-287), (Musekamp 202-248), Grzelak (371-397). Nie wszystkie one stanowią jedynie materialne świadectwa zależności. $\mathrm{W}$ polskich miastach, $\mathrm{w}$ tym także Szczecinie, naznaczanie przestrzeni miejskiej nie zawsze jednoznacznie kojarzone było z zewnętrzną dominacją. Wspomnieć można choćby licznie powstające po wojnie pomniki Mickiewicza czy pomniki upamiętniające polskie bohaterstwo w czasie II wojny światowej. Te ostatnie projektowano zgodnie $\mathrm{z}$ obowiązującym, podyktowanym ideologią wzorcem, ale mieszkańcy miast traktowali je jako zdecydowanie polskie, a ich wartość artystyczna często była i jest doceniana ponad ideologicznym za- 
barwieniem charakteryzującym epokę komunizmu. Pomniki takie istnieją w Polskich miastach obok tych, które wznoszone były po wojnie jako narzędzia propagandowe sensu stricto, jak to miało miejsce choćby w przypadku powstających masowo obelisków upamiętniających "braterską walkę" polskich i radzieckich żołnierzy (Grzesiuk-Olszewska 46-63).

W Szczecinie tuż po wojnie, w okresie kluczowym dla powstawania polskiego nazewnictwa ulic i placów zwraca uwagę stosunkowo niewielki wpływ obowiązującej wykładni politycznej. Bezpośrednie odwołania do Związku Radzieckiego zaznaczyły się na szczecińskiej mapie $\mathrm{w}$ bardzo niewielkim stopniu - były to bowiem jedynie dwie ulice i dwa place (Grzelak 382). Wielką, pozytywną rolę odegrała tu architektka i urbanistka Helena Kurcyuszowa, działająca w ramach Komisji do Zmiany Nazw Ulic funkcjonującej pod przewodnictwem Józefa Kijowskiego. Zaproponowane przez nią nazewnictwo przyjęło się w Szczecinie z dużym powodzeniem. Obfitowało zarówno w odwołania do polskich poetów, artystów czy polskiej historii, jak i stanowiło wyraz jej wielkiej, subtelnej inwencji twórczej myślę tu choćby o takich nazwach, jak pl. Jasne Błonia, pl. Zgody, ulice: Ku Słońcu, Wiatru od Morza, czy Bohaterów Warszawy (tę ostatnią nazwę zaaplikowano także w innych miastach polskich) (Musekamp 233-235).

Jagoda Wierzejska, analizując przejście od miasta sowieckiego do miasta postsowieckiego zwraca uwagę na szereg „linii ciągłości”, które wskazują na kontynuację sowieckości w przestrzeni miejskiej. Najsilniej fakt ten ukazywać ma „cała, narosła przez dziesiątki lat komunizmu warstwa budowlana" (Wierzejska 412). Z kolei zmiana, którą wyznaczył przełom polityczny 1989 roku ujawniać się ma w "punktach zerwania”, co najdobitniej widoczne ma być w "przejściu od miasta jako bytu państwowego do miasta obywateli" (Wierzejska 417). Refleksja Wierzejskiej pomija w moim przekonaniu bardzo istotną kwestię. Nie da się przyporządkować tego, co zostało zbudowane w epoce komunizmu, jedynie do sfery sowieckiej zależności. Traktowanie powojennej architektury i urbanistyki radzieckiej sfery wpływów w kategoriach wyłącznie sowieckich każe definiować tożsamość tych powojennych miast jaką sowiecką. Powstałe $w$ tamtym czasie zamysły urbanistyczne i architektoniczne dalece wykraczają jednak poza taką kategoryzację.

Miast epoki komunizmu nie sposób zamknąć również w zaproponowanej przez badaczkę definicji miasta państwowego, lokującego się niejako w opozycji do miasta obywatelskiego. Zarówno architektura, jak i przestrzeń symboliczna miast niejednokrotnie kreowana była przez Polaków w taki sposób, by uciec z pułapki sowieckiej zależności. Powstająca wtedy architektura i pomniki pozwalały nie tyle definiować się w jawnej opozycji do sowieckiej opresji, ile sytuować się poza nią. $\mathrm{W}$ przestrzeni miejskiej skupiały się zarówno przejawy radykalnego oporu obywatelskiego, z całą mocą zwalczane przez władzę komunistyczną, jak i występujące obok nich obywatelskie praktyki miękkiego oporu, ujawniające się na masową skalę choćby w czasie pielgrzymek Jana Pawła II. Do pewnego stopnia 
czyniły one miasto państwowe także miastem obywatelskim. Przestrzeń miasta obywatelskiego per se wydaje się zresztą utopią, jako że każdy system władzy wytwarza wobec swoich obywateli szereg ograniczeń dotyczących przestrzeni miejskiej. Nie twierdzę, że miasta sowieckie i postsowieckie nacechowane są takim samym stopniem opresyjności - zwracam jednak uwagę na fakt, iż także miasta istniejące $\mathrm{w}$ orbicie wpływów ZSRR były $\mathrm{w}$ pewnym stopniu animowane przez swoich mieszkańców. Choć działania takie pojawiały się mniej licznie niż po przełomie i często naznaczano je obowiązującym zabarwieniem ideologicznym, to właśnie one doskonale obrazują, jak w alternatywny sposób konstruowana była tożsamość miast doby sowieckiej, które obywatele chcieli, na tyle, na ile było to możliwe, uczynić swoimi. Myślenie o przestrzeni miejskiej tamtego czasu w kategoriach przestrzeni konstruowanej i rekonstruowanej jedynie zewnętrznie czyniłoby niemożliwym jej - niewątpliwie postępujące - oswojenie.

W kontekście powyższych rozważań za kluczowe uważam zatem podkreślenie, iż zależność nie wykluczała budowania osobnej tożsamości miasta. Przykład Szczecina ukazuje ów fakt tym dobitniej, iż jego mieszkańcy, którzy, przybywając głównie ze Wschodu, osiedlili się w mieście po wojnie, przepełnieni często krytyczną świadomością realiów życia pod radzieckim jarzmem, skonfrontowani z niemieckim dziedzictwem miasta, próbowali wytworzyć nową jakość, sytuując się gdzieś pomiędzy jego zastaną, niemiecką tożsamością, a tożsamością definiowaną politycznie $\mathrm{w}$ kategoriach obowiązującej ideologii. Owa dostrzegalna w miejskiej tkance hybrydowość Szczecina znajdującego się między biegunem niemieckim, a radzieckim, nie oznacza bynajmniej prostego złożenia obu tych czynników. Opiera się bowiem przede wszystkim o niemiecko-polsko-radziecką triadę3. Środkowy komponent nadaje jej znaczenie, które pozwala mówić o nowej tożsamości miasta: nie tyle niemieckiej, polskiej i sowieckiej, ile po prostu osobnej, szczecińskiej. Polacy zamieszkujący miasto po wojnie, właśnie tak je oswajali. Pracująca nad odbudową Szczecina, wspomniana już wcześniej, Helena Kurcyuszowa w swoich wspomnieniach pisała:

W Szczecinie czuliśmy się wtedy [w 1945 roku, M.P.] obco. Nie opuszczało nas ani na chwilę poczucie tymczasowości, nietrwałości. Wydawało się nam, że Polska jest tam, na starych ziemiach. Że tam jest życie prawdziwe, a tu jest jakaś egzotyczna kolonia polska, do której oddelegowano nas na okres przejściowy (Kurcyuszowa 184).

Dalej jednak, co symptomatyczne w kontekście oswajania miasta, w tych samych wspomnieniach pierwszych lat życia w Szczecinie pisze już, co następuje:

\footnotetext{
${ }^{3}$ Mam świadomość współistnienia obok także innych komponentów tożsamościowych Szczecina, m.in. żydowskiego, rosyjskiego czy szwedzkiego, jednak świadomie wspominam o tych trzech, jako najbardziej dominujących. Por. (Musekamp 365-367; Wolski 291-300).
} 
Było $w$ tym trochę przypadku, a trochę szczęścia, że mogłam uczestniczyć od samego początku, w dziele tworzenia się nowego życia. Nic dziwnego, że zarówno do Szczecina, jak i do całego województwa mam wyjątkowy sentyment, a także uczucie dumy, jak do czegoś bardzo bliskiego i bardzo mojego. Czuję się po prostu szczecinianką. Teraz, gdy przyjeżdżam do Szczecina, wiem, ze wracam do siebie, do domu (Kurcyuszowa 198).

Oswajanie miasta oznaczało nie tylko przyswojenie niemieckiego dziedzictwa miasta, ale także poczucie uczestniczenia w owym "tworzeniu się nowego życia”, bycia częścią tego, co powstaje, a więc w konsekwencji, przynajmniej w pewnym stopniu, utożsamienia się z tym. Podkreślone przez Helenę Kurcyuszową poczucie bycia „po prostu szczecinianką" pozwala dostrzec, jak istotne było owo utożsamienie z nowym miastem, i fakt zaistnienia osobnej, szczecińskiej tożsamości. Praktyki osobistego oswajania przez mieszkańców Szczecina przestrzeni miejskiej, która ożywa przecież dopiero dzięki ludziom, odzierały ją częściowo ze zideologizowanej wymowy i przenosiły w sferę pozwalającą funkcjonować obok obowiązującej, narzuconej zewnętrznie ideologicznej matrycy. Zależność od politycznego hegemona, która znajdywała odzwierciedlenie również w materialnej przestrzeni otaczającej Polaków, była zależnością uświadamianą, ale też przetwarzaną i oswajaną tak, by choć częściowo mogła stać się przestrzenią osobną.

\section{Zależność i postzależność w materialnej tkance miejskiej Szczecina}

Co przynosiła zatem relacja zależnościowa w kontekście tożsamości przestrzeni miejskiej? Jak w konsekwencji rozumieć można zachodzącą tu postzależność? Kondycja zależnościowa powodowała niewątpliwie, iż Szczecin rozwijał się inaczej niż miasta pozostające bez związku z wyraźnie zdefiniowanym, politycznym hegemonem. Narzucona zewnętrznie wizja świata była i jest w kontekście relacji zależnościowej i postzależnościowej ważnym komponentem przestrzeni miejskiej Szczecina. Zarówno ograniczenia administracyjne, techniczne oraz ideologiczne powodowały, iż działania architektów i urbanistów wymagały ciągłego określania się wobec zewnętrznej siły. Dla mieszkańców powodowały z kolei konieczność nieustannego interpretowania otaczającej ich przestrzeni $\mathrm{w}$ kategoriach przynależności bądź odrzucenia i odrębności. Szereg pomników, nazwy niektórych ulic czy charakter niektórych budynków ze względu na przypisywaną im ideologiczną wymowę przypominały o istnieniu relacji zależnościowej, choć wiele z nich pozbywało się z czasem radzieckiego balastu, którego ideologiczna wymowa ulegała stopniowemu zatarciu. Specyfika Szczecina, pogranicznego dziś miasta o znaczącej niemieckiej tradycji, powodowała ponadto, iż utożsamienie z architekturą, któ- 
ra $\mathrm{w}$ Szczecinie powstawała tu po wojnie, następowało łatwiej niż $\mathrm{w}$ miastach o tradycji polskiej. W przypadku takich miast, jak choćby Warszawa, to, co powstawało po wojnie, było obce wobec polskiego dziedzictwa miasta, z którym wcześniej utożsamiali się warszawiacy. Dużo trudniej było więc zaakceptować zmiany, które wprowadzano w tkance miejskiej i dużo łatwiej można było traktować je jako narzucone zewnętrznie, tym bardziej, że ideologiczna interpretacja powstającej architektury świadczyła o podrzędności Polaków. Powstająca zabudowa przywoływała zatem pamięć o tym, co uległo zniszczeniu, i o tym, co utracono, wywołując cierpienie. W przypadku Szczecina, miasto, które odbudowywano rękami Polaków, powstawało na obcym gruncie oraz wobec obcego dziedzictwa. Powstający z gruzów Szczecin, mimo relacji zależnościowej, był więc bardziej polski i odbierany jako swój, niż to, co wcześniej stanowiło jego miejską tkankę. Utożsamienie $\mathrm{z}$ powstającą przestrzenią mogło dawać satysfakcję oraz paradoksalnie wzmacniać poczucie zakorzenienia i przynależności do nowego miejsca.

Fakt zależności od radzieckiego mocodawcy nie wykluczał tu zatem wyłaniania się jednocześnie tożsamości odrębnej, funkcjonującej poniekąd obok tej narzuconej, która kształtowała częściowo miasto, ale nie definiowała go w pełni. Nazywanie miast istniejących w radzieckiej strefie wpływów "sowieckimi”, a później "postsowieckimi" wskazuje co prawda na ważny czynnik wpływający na ich rozwój, ale sprzyja też niebezpiecznym uproszczeniom i skrótom myślowym, które unifikują miasta znajdujące się $\mathrm{w}$ relacji zależności od Związku Radzieckiego. Wpływ ZSRR na rzeczywistość jego państw satelickich, a więc także na ich przestrzeń miejską, posiadał w drugiej połowy XX wieku różną dynamikę. Inaczej wyglądał w czasach stalinowskich, a inaczej - choćby w latach 80 . XX wieku. Ponadto analiza konkretnych przypadków dowodzi, iż kultura państw pozostających $\mathrm{w}$ zależności od ZSRR miała istotny wpływ na to, jak odbieramy dane miasto, i jaka jest jego miejska tkanka. Zwrócenie uwagi na specyfikę państw satelickich wydobywa zatem wielorakie i różnicujące tożsamości poszczególnych, "postsowieckich" miast. Zależność od ZSRR, która była matrycą przekładalną na miasta istniejące w tej strefie wpływów, stanowi jedynie czynnik, nie uniwersalną sztampę pozwalającą zgłębić ich kulturową przestrzeń i jest jednym z licznych nawarstwień kulturowych, podlegającym różnym mechanizmom oswajania, odrzucania i odrywania od przypisanych im pierwotnie znaczeń.

Szczecin obfituje w szereg przykładów wskazujących na wieloznaczność odczytań jego powojennej tkanki miejskiej zarówno w czasach przed, jak i po przełomie 1989 roku. Świadczą one tak o kondycji kolonialnej Szczecina, jak i o jego postkolonialnym charakterze. Dobitnym przykładem „instalowania” radzieckiej ideologii na terenie Szczecina było wzniesienie w 1950 roku Pomnika Wdzięczności dla Armii Radzieckiej - typowego narzędzia propagandowego ówczesnej epoki. Usytuowano go w miejscu, w którym wcześniej znajdował się Pomnik Wilhelma I (Musekamp 206-207). W ten sposób przejęto niemiecką przestrzeń symbo- 
liczną czyniąc z niej radziecką domenę symboliczną. To na linii Niemcy - ZSRR odbyło się w Szczecinie pierwsze symboliczne „znaczenie" terytorium. Uczestnictwo pomnika w życiu miasta ograniczało się jednak jedynie do zrytualizowanych praktyk urzeczywistniających obowiązująca politykę historyczną, takich jak odbywanie oficjalnych uroczystości u jego stóp. Pomnik nie został przez szczecinian oswojony. Traktując go jako świadectwo zależności nie identyfikowali się z nim i odrzucali narzucone przez niego przesłanie. Fakt ten ujawniał się z jednej strony $\mathrm{w}$ braku nielegitymizowanych przez państwo praktyk włączających go w nurt codziennego życia mieszkańców miasta, czy w aktach wandalizmu wymierzonych w pomnik. Obcość i brak akceptacji najdobitniej chyba ilustrują słowa przywołanych przez Jana Muskampa wstępnych założeń budowy pomnika Mickiewicza w Szczecinie z 1956 roku. Jak podaje autor monografii, można w nich przeczytać, iż "Szczecin, miasto ćwierć milionowe [...] nie posiada dotychczas żadnego pomnika" (Musekamp 209-210). Brak przywiązania do monumentu i codzienna obojętność wobec niego ilustrują, jak szczecinianie radzili i radzą sobie z dziedzictwem świadczącym o zależności. Ignorowanie pomnika wdzięczności, traktowanie go tak, jakby nie istniał zarówno przed, jak i po upadku komunizmu, przy jednoczesnym zachowaniu go $\mathrm{w}$ przestrzeni miasta, które nie czyni z minionej epoki przysłowiowej „białej plamy”, z powodzeniem uznać można za jedną ze strategii postkolonialnych radzenia sobie z narzuconą niegdyś ideologią4.

Inny przykład stanowi Pomnik Czynu Polaków. Jest on ciekawą ilustracją odrywania znaczenia pomnika od propagandowej wymowy, oswajania go oraz wyjścia poza pułapkę upraszczającego traktowania narosłej $\mathrm{w}$ czasach komunizmu tkanki miasta jako jednoznacznie obcej, zewnętrznej i świadczącej jedynie o sowieckości miast bloku wschodniego i ich przynależności do sfery radzieckiej przestrzeni symbolicznej. O budowie pomnika zadecydowano w 1972 roku na plenum KW PZPR, a odpowiedzialnym za realizację monumentu uczyniono Wydział Propagandy i Kultury KW PZPR w Szczecinie. Pomnik w zamyśle miał symbolizować „pracę i wkład naszego województwa w rozkwit Polski Ludowej”, a więc poniekąd „rozkwit” polsko-radzieckiej zależności. Nadana pomnikowi nazwa także świadczyła o jego przynależności do obcej przestrzeni symbolicznej. Prace nad pomnikiem rozpoczęto ostatecznie w 1976 roku powołując Komitet Organizacyjny Budowy Pomnika. Przyjęto koncepcję artystyczną "trzech orłów - trzech pokoleń" i w 1969 roku na Jasnych Błoniach dokonano odsłonięcia monumentu. Zaprojek-

${ }^{4}$ Nie dokonano zburzenia pomnika zaraz po przełomie 1989 roku, a pojawiające się niekiedy w latach późniejszych pomysły o jego rozebraniu nie mogły zostać zrealizowane choćby ze względu na obowiązującą między Polską a Rosją umowę dotyczącą ochrony grobów i miejsc pamięci ofiar wojen i represji. Dziennik Ustaw nr 112, poz. 543, 22.2.1994 r.

${ }^{5}$ http://www.szczecin.pl/umszczecinswiat/chapter_59232.asp?soid=6955E9A88B8640818F2E7A 0753C51426 (data dostępu: 30.07.2014). 
towana przez Gustawa Zemłę rzeźba wymykała się jednak świadectwu zależności przestrzeni symbolicznej od dominującego, zewnętrznego hegemona. Sięgnięcie po symbol orła, czytelny dla Polaków i utożsamiany z polskim patriotyzmem pozwalał utożsamić się szczecinianom z pomnikiem. Świadczą o tym słowa samego autora projektu, który stwierdził: „Nadałem pomnikowi kształt wzbijających się orłów (...) bowiem wydawało mi się, ze orzeł jest tym symbolem najpojemniejszym, świadczącym o polskości, patriotyzmie, walce i pracy" (Grzesiuk-Olszewska 152). Jednocześnie jednak przywołanie orła mieściło się w propagandowej estetyce PRL-u, podkreślającej na szczecińskim gruncie „odwieczną" polskość miasta. W warstwie propagandowej i retorycznej pomnik obudowany był rzecz jasna wszelkimi odwołaniami do obowiązującej linii ideologicznej wyznaczonej przez PRL-owską propagandę, jednak w praktyce życia codziennego wymowa pomnika odczytywana była zupełnie inaczej, a pomnik stał się monumentem bliskim szczecinianom. Oderwanie od propagandowego znaczenia następowało w różnoraki sposób, m.in. poprzez zmianę nazwy. Potocznie pomnik zafunkcjonował bowiem pod nazwą „Orlego gniazda” lub „Pomnika Trzech Orłów”. Innym czynnikiem pozwalającym na osobistą identyfikację z monumentem było przesłanie koncentrujące się na odwołaniu do trzech pokoleń szczecinian symbolizowanych przez trzy orły, które dawało tak ważne w tym przypadku poczucie przynależności do miasta.

Nie tylko jednak pomniki, mogące stanowić doskonałe narzędzie polityczne per se, podlegały wypomnianym wyżej mechanizmom. Przykładem obiektu, który powstał w Szczecinie w czasach PRL-u, ale nie był traktowany jako wyraz polskiej zależności od ZSRR, a w ostatnich latach doczekał się uznania, jako wartościowy przykład architektury modernistycznej, było wzniesione w 1959 roku kino Kosmos zaprojektowane przez Andrzeja Korzeniowskiego. Kino zostało zamknięte w 2004, ale już w 2006 zostało wpisane do rejestru zabytków i objęte ochroną. W 2013 roku rozpoczęto natomiast prace rewitalizujące obiekt. Choć projekt rewitalizujący kino wzbudza kontrowersje, docenienie budynku, sentymenty i dyskusje, które toczone są na jego temat, świadczą o tym, że nie traktuje się go jako wytworu socjalistycznej ideologii.

O zrzucaniu balastu konotowanego negatywnie dziedzictwa czasów komunizmu świadczy także stosunek do innych obiektów powstałych w mieście, takich jak np. tzw. "grzybek”, zaprojektowany również przez Andrzeja Korzeniowskiego czy renowacja budynku „Kaskady” (Szymski 90). Coraz częściej uznaniem cieszą się także niektóre, z powstałych w okresie PRL-u, zespoły osiedli mieszkaniowych. $\mathrm{W}$ ich przypadku docenia się tereny zieleni projektowane wraz z osiedlami, doświetlenie i przewietrzenie mieszkań czy odległości między budynkami (Latour 17; Springer).

W przestrzeni miejskiej Szczecina znajduje się także inny, warty wspomnienia przykład, który ukazuje z kolei wieloznaczność relacji kolonialnych/postkolonial- 
nych na styku niemiecko-polsko-radzieckim. Chodzi tu o Zamek Książąt Pomorskich z rodu Gryfitów. Odbudowa zamku obwarowana była całym zestawem propagandowych zabiegów legitymizujących polskie prawo do Szczecina, czyniąc odbudowywany zamek składnikiem mitu „Ziem Odzyskanych”. Wymierzona w Niemców pełna nadużyć retoryka nie była jednak traktowana jako element opresyjnej propagandy narzuconej przez radzieckiego ciemiężyciela i w dużej mierze została zaakceptowana przez Polaków, choć oni sami podobnie upokarzani byli przez propagandową wymowę politycznego uzależniania Polski od ZSRR i jej „wyzwalania” przez Armię Czerwoną. Krzywdząca była nie tyle sama odbudowa i waga znaczenia zamku dla polskiego Szczecina oraz fakt, że stał się on istotnym dla szczecinian miejscem umożliwiającym identyfikację z miastem, ile jej ideologiczna interpretacja. To ona naznaczona została wykluczającą, kolonialną przemocą symboliczną, w której uczestniczyli Polacy.

Ostatnim, bardzo interesującym przykładem świadczącym z kolei o postkolonialnej kondycji miasta, który podkreśla specyfikę Szczecina, jest z kolei właśnie zmiana stosunku do dziedzictwa niemieckiego. Zaczęła ona następować stopniowo, począwszy od lat 90. XX wieku. Doskonały przykład stanowi tu docenienie niemieckich szczecinian przy okazji nadawania nazw ulic. Przemianowywanie nazw ulic i placów stanowi wyraz powszechnej i zrozumiałej praktyki zerwania z narzuconym dziedzictwem, jednak zwrot, który nastąpił przy tej okazji w Szczecinie świadczy nie tylko o wzmocnieniu niezależnego, polskiego oblicza miasta, ale także o podkreśleniu jego specyfiki i wartości regionalnej. W 1996 roku jednej $\mathrm{z}$ ulic nadano imię niemieckiego podróżnika i ornitologa Paula Robiena, a w roku 2011, nowo powstałe rondo mianowano imieniem zasłużonego dla miasta niemieckiego nadburmistrza Hermanna Hakena, który m.in. wprowadził w Szczecinie powszechny układ komunikacyjny rond czy przebudował słynne Wały Chrobrego (niegdyś właśnie Hakenterrasse) (kochamszczecin.pl). Jan Musekamp słusznie zwraca uwagę, iż wciągnięcie w przestrzeń symboliczną miasta tradycji niemieckiej świadczy o swoistym zwrocie lokalnym, który dostrzec można w Szczecinie rozwijającym się niezależnie od 1989 roku (Musekamp 357-365)6. Praktyka dekolonizacyjna, która z jednej strony polega na nadawaniu nowego, niezależnego nazewnictwa miejskiej infrastrukturze, w przypadku Szczecina oznacza także odcięcie się od antyniemieckiej propagandy doby komunizmu, która stanowiła istotny składnik konstruowania polskiej tożsamości miasta w drugiej połowie $\mathrm{XX}$ wieku, co w sposób dobitny widoczne było choćby w przypadku Zamku Książąt Pomorskich. Proces ten pokazuje, jak można próbować szukać przejść od dyskursów wykluczenia do dyskursów koncyliacyjnych, o których pisał Bogusław Bakuła

\footnotetext{
${ }^{6}$ Warto podkreślić, iż Musekamp zarówno docenia odwagę Polaków, którzy przywracają miastu także niemieckie oblicze, $\mathrm{z}$ drugiej jednak strony słusznie dostrzega porażki w zmianie podejścia do wielowarstwowej historii miasta.
} 
i starać się radzić z słusznie przez niego podnoszoną problematycznością kwestii „pamięci, kulturowego zakorzenienia i prawa do udziału w kształtowaniu trudnej, wspólnej przeszłości" (Bakuła 140). Nowa jakość, ujawniająca się przy okazji przytoczonego tu przykładu dowodzi, jak miasto peryferyjne, ale jednocześnie i pograniczne, staje się miastem świadomym swego różnorodnego pejzażu kulturowego, który czyni go wyjątkowym.

Pograniczna specyfika Szczecina oznacza przynależność do różnych przestrzeni kulturowych. Przebadanie Szczecina w perspektywie postkolonialnej pozwala dostrzec mechanizmy kolonialne i postkolonialne charakteryzujące miasta o zmieniającej się przynależności politycznej. Wydobywa też jednak z pełną mocą specyfikę Szczecina - jego osobną, lokalną tożsamość. W ten sposób pozwala dostrzec jego odrębność, która nie daje się zdefiniować jedynie poprzez jednowymiarową postsocjalistyczną kategoryzację, jak i przez podszytą kompleksami tęsknotę za "lepszym” i „prawdziwym” zachodnim, europejskim światem. Analiza szczecińskiej tkanki miejskiej pozwala ponadto wyrazić sprzeciw zarówno wobec tez unifikujących miasta bloku wschodniego, jak i wobec jednowymiarowego, upraszczającego obrazu stosunku do materialnych świadectw epoki minionej zależności.

\section{BIBLIOGRAFIA}

Bakuła, Bogusław. „Studia postkolonialne w Europie Środkowej oraz Wschodniej 1989-2009. Kwerenda wybranych problemów w ramach projektu badawczego". Kultura po przejściach, osoby z przeszłością. Polski dyskurs postzależnościowy - konteksty i perspektywy badawcze. Red. R. Nycz. Kraków: Universitas, 2011. S. 137-165.

Basista, Andrzej. Betonowe dziedzictwo. Architektura w Polsce czasów komunizmu. Warszawa: Wydawnictwo Naukowe PWN, 2001.

Brencz, Andrzej. „Oswajanie niemieckiego dziedzictwa kulturowego. Z badań etnologicznych na Środkowym Nadodrzu". Wokót niemieckiego dziedzictwa kulturowego na Ziemiach Zachodnich i Pótnocnych. Red.: Z. Mazur. Poznań: Instytut Zachodni, 1997. S. 191-216.

Chrudzimska - Uhera, Katarzyna. „Rzeźba w mieście. Pomiędzy polityką a estetyką - wybrane zagadnienia z historii polskiej rzeźby pomnikowej i plenerowej w latach 1945-1980". Pod dyktando ideologii. Studia z dziejów architektury i urbanistyki w Polsce Ludowej. Red. P. Knap. Szczecin: IPN Szczecin, 2013. S. 277-287.

Grzelak, Jerzy. „Wizja szaty ideologicznej miasta w koncepcji urbanistyki socjalistycznej na przykładzie nazw ulic i placów Szczecina w latach 1945-1990". Pod dyktando ideologii. Studia z dziejów architektury i urbanistyki w Polsce Ludowej. Red. P. Knap. Szczecin: IPN Szczecin, 2013. S. 371-397.

Grzesiuk-Olszewska, Irena. Polska rzeźba pomnikowa w latach 1945-1995, Warszawa: NERITON, 1995.

Hannertz, Ulf. Odkrywanie miasta. Antropologia obszarów miejskich. Kraków: Wydawnictwo Uniwersytetu Jagiellońskiego, 2006.

Hobsbawm, Eric. „Wprowadzenie. Wynajdywanie tradycji”. Tradycja wynaleziona. Red. E. Hobsbawm, T. Ranger. Kraków: Wydawnictwo Uniwersytetu Jagiellońskiego, 2008. S. 9-23. 
Kibort, Piotr. „Ideologia i estetyka w urbanistyce i architekturze okresu odbudowy Polski w latach 1945-1949 (projekty - realizacje - propaganda)". Pod dyktando ideologii. Studia z dziejów architektury i urbanistyki w Polsce Ludowej. Red. P. Knap. Szczecin: IPN Szczecin, 2013.

Kołodziejczyk, Dorota. „Gdzie jest miejsce dla Europy Środkowej i Wschodniej w przestrzeni postkolonialnej? Możliwe trajektorie podróży". Porównania 13 (2013). S. 9-27.

Kołodziejczyk, Dorota. „Postkolonialny transfer na Europę Środkowo-Wschodnią”. Kultura po przejściach, osoby z przesztością. Polski dyskurs postzależnościowy - konteksty i perspektywy badawcze. Red. R. Nycz. Kraków: Universitas, 2011. S. 117-136.

Kotkin, Joel. The City. New York: Modern Library, 2005.

Kurcyuszowa, Helena. „Moje pierwsze lata w Szczecinie. Fragmenty wspomnień”. Przegląd Zachodniopomorski 3 (1994). S. 167-198.

Latour, Stanisław. „Przemiany w przestrzeni miast zabytkowych na Pomorzu Zachodnim po II wojnie światowej". Sztuka XX wieku w Szczecinie i na Pomorzu Zachodnim. Przemiany i kontynuacje. Red. M. Gliński, R. Makała. Szczecin: IPN Szczecin, 2008. S. 11-26.

Lisiak, Agata. „(Post)kolonialne miasta Europy Środkowej”. Porównania 6 (2009). S. 137-148.

Musekamp, Jan. Między Stettinem a Szczecinem. Metamorfozy miasta od 1945 do 2005. Poznań: Wydawnictwo Nauka i Innowacje, 2013.

Nic nie jest milczeniem. Wspomnienia stuchaczy Uniwersytetu Trzeciego Wieku w Szczecinie. Red. B. Bugajska, G. Kondraciuk-Gabryś, W. Homa. Szczecin: Zapol, 2010.

Nycz, Ryszard. „Wprowadzenie. „Nie leczony, chroniczny pogłos”. Trzy uwagi o polskim dyskursie postzależnościowym". Kultura po przejściach, osoby z przesztościa. Polski dyskurs postzależnościowy konteksty i perspektywy badawcze. Red. R. Nycz. Kraków: Universitas, 2011. S. 5-6.

Sachanowicz, Tomasz. „Zabytki architektury PRL kiedyś i dziś”. Web. 04.09.2015. http://www.bryla. pl/bryla/56,85301,13735755,Kino_Kosmos_Szczecin_1959_projekt_arch_Andrzej,,7.html

Snochowska-Gonzales, Claudia. „Do kogo należy polska krytyka postkolonialna?” Postkolonializm i postsocjalizm we wspótczesnej Polsce. Red. R. Geisler. Dobrzeń Wielki: Agencja Managerska VIP for You, 2013. S. 16-30.

Springer, Filip. Źle urodzone: reportaże o architekturze PRL-u. Kraków: Karakter, 2011.

Szymski, Adam M. Architektura i architekci Szczecina (1945-1995). Architektura Szczecina na tle osiagnięć polskiej architektury wspótczesnej. (Próba syntezy). Szczecin: Wydawnictwo Uczelniane Politechniki Szczecińskiej, 2001.

Turek, Janina. Wspomnienia. Rękopis. S. 41-42.

Web. 04.09.2015. http:// kochamszczecin.pl/index.php/ludzie-szczecina/80-hermann-haken

Wierzejska, Jagoda. „Hermeneutyka przestrzeni postsowieckiej. Próba zarysu”. Historie, społeczeństwa, przestrzenie dialogu. Studia postzależnościowe w perspektywie porównawczej. Red. H. Gosk, D. Kołodziejczyk. Kraków: Universitas 2014. S. 405-421.

Wolski, Paweł. „Po(st)graniczne narracje miejskie. Literackie Re-konstrukcje żydowskiego Szczecina”. Porównania 11 (2012). S. 291-300.

Zaremba, Piotr. Walka o polski Szczecin. Wrocław: Zakład Narodowy im. Ossolińskich, 1986.

Zaremba, Piotr. Wspomnienia prezydenta Szczecina 1945-1950. Poznań: Wydawnictwo Poznańskie, 1980. 